THE SPATIAL ANALYSIS OF KITE HOME INDUSTRY

IN GROGOL VILLAGE, GROGOL SUB DISTRICT

SUKOHARJO DISTRICT IN 2018

Aldino Itok Pramono ${ }^{1}$, MS Khabibur Rahman ${ }^{2}$, Muh. Husyain Rifa'i ${ }^{3}$

1,2,3 Geography Education Study Program, Sukoharjo Veteran Bangun

Nusantara University

\begin{abstract}
The research objective was to find out: (1) Distribution of kite industry homes, (2) social and economic conditions of kite craftsmen, (3) Factors of production and production that support the existence of kite home industries in Grogol Village, Grogol District Sukoharjo. The study used a spatial description data analysis method obtained from the Central Bureau of Statistics of Sukoharjo Regency and used questionnaire questionnaire and data calculation using the frequency table formula. The data contains data from interviews. Data collection techniques used are through interviews, observation and documentation. Data analysis techniques use spatial correlation. The results of the study are: (1) Distribution of kite industry home in 2018 which has a total of 20 industries (2) The social and economic conditions of kite craftsmen in Grogol Village in 2018 are quite good (3) Factors supporting the production of kites includes raw materials, business capital, labor, marketing, and industrial locations.

Keywords: distribution, socio-economic, production
\end{abstract}




\section{A. INTRODUCTION}

\section{Research Background}

Industry is a business or activity in processing raw materials or semifinished goods into finished goods that have added value to gain profit. Assembling and repair businesses are part of the industry. Industrial products are not only in the form of goods, but also in the form of services. Industry is an important economic sub-sector in development, the industrial sector is believed can lead other sectors in economic development.

The Industrial Sector is sector that plays an important role in national development. By year, the contribution of the Industrial sector to national development shows a significant contribution. The role of the Industrial Sector in National Economic Development can be traced from the contribution of each sub-sector to the National Economic Growth Rate or to Gross National Domestic Product (Produk Domestik Nasional Bruto in Bahasa), which is expected able to solve unemployment problems by absorbing labor force.

Home industry can be regarded as a small-scale home business. According to Law No. 9 of 1995 home industry/ small business is small-scale economic activities of people and meets the criteria of net worth or annual sales proceeds and ownership as stipulated in the law. Home industries have taken place in labor and job opportunities. This is because the home industry is labor or manpower intensive, because it requires a lot of labors both adult and adolescent workers who have special skills. The workforce usually comes from the surrounding environment and the family nearby.

The existence of a home industry has great socio-economic influence for people since it can be an additional income to be used as a daily livelihood. The association of a group of people in an industrial forum will have a great effect on the formation of psychological and emotional 
networks among individuals. The striking difference among people can fade away and be replaced by a sense of security and enthusiasm to maintain the group.

In the area of Grogol Village, Grogol District, there are various types of industries, both home industry and large-scale industries. One of home industries is an industry that is engaged in the game or hobby, namely the kite home industry.

Kite home industry in Grogol began to develop because it has been considered to have influence on fulfilling the needs of people and reducing the number of unemployed. Initially, the existence of the kite home industry in Grogol village was not becoming livelihood, but then it began to develop and to absorb labor who are coming from surrounding community who wanted to have additional income besides working in the factory. Most workers in this home industry are female who have more time spent at home than men. The development of this industry cannot be separated from the production factors including raw materials, capital, sources of labor, transportation and marketing.

From the description above, the background of the research is entitled "Spatial Analysis of Kite Home Industry in Grogol Village, Grogol District, Sukoharjo Regency in 2018"

\section{Problem Identification}

Based on the background description above, the main problems related to the social and economic conditions of kite Home Industry craftsmen in Grogol Village, Grogol Sub-District, Sukoharjo Regency are identified as follows:

1. There is a kite home industry in Grogol Village, Grogol Sub-District.

2. This industy has influence on the social and economic conditions of craftsmen. 
3. The are production factors and production output that support the existence of kite home industry in Grogol Village, Grogol District, Sukoharjo Regency.

\section{Problem Restriction}

Based on the background and problem identification above, it is necessary to limit the problems as follows:

1. The distribution of kite-making home industry in Grogol Village, Grogol Sub-District.

2. The social and economic conditions of kite craftsmen in Grogol Village, Grogol District, Sukoharjo Regency, are limited to the number of family dependents, length of business and income level.

3. The production factors of home kite industry in Grogol Village, Grogol District, Sukoharjo Regency, are limited to business capital, raw materials, business capital, labor, marketing and the location of home industries.

\section{Problem Formulation}

Based on the limitations of the problems described above, several problems can be formulated relating to this research, including the following:

1. How is the distribution of kite industry home in Grogol Village, Grogol District?

2. What are the social and economic conditions of kite craftsmen in Grogol Village, Grogol District, Sukoharjo Regency?

3. What factors that influence the existence of kite home industry in Grogol Village, Grogol District, Sukoharjo Regency? 


\section{Research Aims}

Based on the formulation of the problem described above, the goals of this study are:

1. To find out the distribution of kite home industry in Grogol Village, Grogol District.

2. To find out the social and economic conditions of kite craftsman community in Grogol Village, Grogol District, Sukoharjo Regency

3. To find out the production factors that influence the existence of kite home industry in Grogol Village, Grogol District, Sukoharjo Regency

\section{Research Benefits}

1. Practical benefits

a. Practical benefits for researchers

The results of this study are expected able to increase knowledge in the field of geography, specifically the population and industrial geography, specifically the influence of the existence of kite home industry on the social and economic conditions of the craftsmen community.

b. Practical benefits for readers

With this research, it can be used as a reference to add insight as a reader.

c. Practical benefits for the community

With this research, it is expected that public will know the existence of kite home industry towards the socio-economic conditions of craftsmen in Grogol Village, Grogol District, Sukoharjo Regency

2. Theoretical benefits

a. The result of this study can give science contribution, especially in the field of geography education

b. Become a reference for further development in education field 


\section{Research Methods}

Hadari Nawawi in Pabundu Tika (2005: 2) states that research method is a science that discusses scientific methods in exploring the truth of knowledge. This research uses descriptive qualitative method.

According to Bogdan and Taylor in Moleong (2012: 4) qualitative descriptive methodology is a research procedure that produces descriptive data in the form of written or oral words from people and observable behavior. This approach is directed at the background and the individual holistically, so it not only produces individuals / organizations into variables / hypotheses, but also needs to view as whole part.

This study uses descriptive qualitative, namely describing Social Economy and production factors related to the existence of kite industry in Grogol Village, Grogol Sub-District, Sukoharjo Regency.

Beside describing the two things, this study also describes the distribution of kite industry that was obtained by plotting method to find out the industrial location, which is illustrated through a map of kite industry distribution in Grogol Village, Grogol District, Sukoharjo Regency.

\section{B. RESULTS AND DISCUSSION}

\section{Distribution of Industrial Locations}

Grogol Village, Grogol Subdistrict Sukoharjo Regency is the sole village in Sukoharjo Regency that has a home industry-based industrial center engaged in flying kites. The distribution of this industry is not evenly distributed throughout the village, yet it is only centered in the hamlet of Bacem.

Bacem hamlet, which is well-known for its kite production, is still running kite home industry and experiencing increased sales compared to the previous year. The sale of kite products produced by inhabitant of Bacem Hamlet is very extensive, not only in the Solo area but also in East Java. 
The number of kite home industries found in Grogol Village is around 20 craftsmen who are connected to each other, so there is no shortage of raw materials or difficult in the sales process. The location between industries is not far away or clustered, making it easier for buyers to buy or just see the process of making kites.

Table 1. The location of Kite Home Industry

\begin{tabular}{|c|c|c|c|c|}
\hline No & Name & $X$ & $\mathrm{Y}$ & Address \\
\hline 1 & Widodo & $110^{\circ} 49^{\prime} 15^{\prime \prime}$ & $7^{\circ} 36^{\prime} 31,15^{\prime \prime}$ & Dk. Bacem RT 01/ RW 05 \\
\hline 2 & Wito & $110^{\circ} 49^{\prime} 9,814^{\prime \prime}$ & $7^{\circ} 36^{\prime} 39,13^{\prime \prime}$ & Dk. Bacem RT 04/ RW 05 \\
\hline 3 & Giarto & $110^{\circ} 49^{\prime} 10,12^{\prime \prime}$ & $7^{\circ} 36^{\prime} 40^{\prime \prime}$ & Dk. Bacem RT 03/ RW 05 \\
\hline 4 & Nanang & $110^{\circ} 49^{\prime} 11,05^{\prime \prime}$ & $7^{\circ} 36^{\prime} 36,3^{\prime \prime}$ & Dk. Bacem RT 03/ RW 05 \\
\hline 5 & Rubiem & $110^{\circ} 49^{\prime} 11,1$ & 7०36'37,2” & Dk. Bacem RT 03/ RW 05 \\
\hline 6 & Pur & $110^{\circ} 49^{\prime} 11,4^{\prime \prime}$ & $7^{\circ} 36^{\prime} 36,8^{\prime \prime}$ & Dk. Bacem RT 02/ RW 05 \\
\hline 7 & Wardoyo & $110^{\circ} 49^{\prime} 11,86^{\prime \prime}$ & $7^{\circ} 36^{\prime} 36,35^{\prime \prime}$ & Dk. Bacem RT 02/ RW 05 \\
\hline 8 & Yanto & $110^{\circ} 49^{\prime} 10,37^{\prime \prime}$ & 7०36'35,91" & Dk. Bacem RT 01/ RW 05 \\
\hline 9 & Suyono & $110^{\circ} 49^{\prime} 12,41^{\prime \prime}$ & 7०36'35,37'” & Dk. Bacem RT 05/ RW 05 \\
\hline 10 & yusuf & $110^{\circ} 49^{\prime} 13,90^{\prime \prime}$ & $7^{\circ} 36^{\prime} 31,5^{\prime \prime}$ & Dk. Bacem RT 05/ RW 05 \\
\hline 11 & Sutopo & $110^{\circ} 49^{\prime} 11,1^{\prime \prime}$ & $7^{\circ} 36^{\prime} 37,2^{\prime \prime}$ & Dk. Bacem RT 05/ RW 05 \\
\hline 12 & Susilo & $110^{\circ} 49^{\prime} 10,3^{\prime \prime}$ & 7०36’32,2” & Dk. Bacem RT 04/ RW 05 \\
\hline 13 & Sarni & $110^{\circ} 49^{\prime} 13,1^{\prime \prime}$ & 7०36'39, $1^{\prime \prime}$ & Dk. Bacem RT 05/ RW 05 \\
\hline 14 & Indri & $110^{\circ} 49^{\prime} 11,2^{\prime \prime}$ & $7^{\circ} 36^{\prime} 38,7^{\prime \prime}$ & Dk. Bacem RT 05/ RW 05 \\
\hline 15 & Wari & $110^{\circ} 49^{\prime} 11,7^{\prime \prime}$ & 7०36'37,4”' & Dk. Bacem RT 04/ RW 05 \\
\hline 16 & Wisnu & $110^{\circ} 49^{\prime} 11,7^{\prime \prime}$ & 7०36'39,2”' & Dk. Bacem RT 05/ RW 05 \\
\hline 17 & Sigit & $110^{\circ} 49^{\prime} 14^{\prime \prime}$ & 7०36’37,2”' & Dk. Bacem RT 04/ RW 05 \\
\hline 18 & Rusmini & $110^{\circ} 49^{\prime} 13,1^{\prime \prime}$ & 7०36'33,2”' & Dk. Bacem RT 02/ RW 05 \\
\hline 19 & Dono & $110^{\circ} 49^{\prime} 13,7^{\prime \prime}$ & 7०36'32,7'” & Dk. Bacem RT 02/ RW 05 \\
\hline 20 & Kelsa & $110^{\circ} 49^{\prime} 14,2^{\prime \prime}$ & $7^{\circ} 36^{\prime} 31,8^{\prime \prime}$ & Dk. Bacem RT 02/ RW 05 \\
\hline
\end{tabular}

Source : Field Survey 2018

There are 20 craftsmen of kite home industry in Grogol village who know and help each other well if one of the craftsmen runs out of stock of kites. 


\section{Description of the social and economic conditions of craftsmen.}

The socio-economic conditions that will be discussed in this study include the level of education, the level of health, and the information of respondents who are focussed on the social conditions of kite craftsmen in Grogol Village, Grogol District, Sukoharjo Regency.

\section{a. Level of education}

The formal education level of kite craftsmen in Grogol Village, Grogol District is shown in table 4.6. The highest level of formal education is high school by $75 \%$ and the least is graduating from tertiary institutions by $10 \%$. Others are graduated from junior high school by $15 \%$.

Table 2. The Formal Education Level Of Head Of Family

\begin{tabular}{llrll}
\hline No & \multicolumn{2}{l}{ Education Level } & Total & $\%$ \\
\hline 1 & $\begin{array}{l}\text { Graduated } \\
\text { School }\end{array}$ & Elementary & - & - \\
2 & $\begin{array}{l}\text { Graduated Junior } \\
\text { School }\end{array}$ & High & 3 & 15 \\
3 & Graduated Senior & High & 15 & \\
& $\begin{array}{l}\text { School } \\
4\end{array}$ & & & 75 \\
5 & Graduated University & & 2 & 10 \\
\hline Total & & - & - \\
\hline
\end{tabular}

Source : Research Data Analysis 2018

Based on above statements, it can be said that the education level of kite craftsmen in Grogol Village is relatively moderate because most of the craftsmen have already attended high school education, while kite craftsmen in Grogol Village also have undergraduate tertiary education. 
But among craftsmen there are still those who have low levels of education such as junior high school but it only has less number.

\section{b. Health Level}

The health Level of kite craftsmen in study area is shown in table 4.8. The table discusses the health level of craftsmen that is possibly caused by occupational risks and pollution.

Table 3. The Health Level of Kite Craftsmen

\begin{tabular}{|c|c|c|c|}
\hline No & Health Level & Total & $\%$ \\
\hline 1 & Healthy & 20 & 100 \\
\hline 2 & Sick & - & - \\
\hline \multicolumn{2}{|c|}{ Total } & 20 & 100 \\
\hline
\end{tabular}

Source : Research Data Analysis 2018

From the table above, it can be concluded that all kite craftsmen in Grogol Village did not experience health problems and interference due to ongoing kite production processes.

\section{c. The results of Kite Craftsmen Research Questionnaire in Grogol}

\section{Village}

Researcher used questionnaires as a reference to obtain high validity output. To do so, several questions related to socio-economic conditions of kite craftsmen in the Grogol Village are compiled as research instrument in this study.

Researcher used interview as the most suitable step to obtain craftsman data. The data obtained is based on reality in the field and there is no coercion during the interview process so it will create high accuracy results. Not only researchers who feel benefited but craftsmen also feel comfortable during the interview process. 
Table 4. The Participant's Background

\begin{tabular}{|c|c|c|c|c|c|}
\hline No & Name & Address & Sex & Occupation & Grade \\
\hline 1 & Widodo & $\begin{array}{l}\text { Dk. Bacem RT 01/ } \\
\text { RW } 05\end{array}$ & Male & Craftsmen & 44 \\
\hline 2 & Wito & $\begin{array}{l}\text { Dk. Bacem RT 04/ } \\
\text { RW } 05\end{array}$ & Male & Craftsmen & 51 \\
\hline 3 & Giarto & $\begin{array}{l}\text { Dk. Bacem RT 03/ } \\
\text { RW 05 }\end{array}$ & Male & Craftsmen & 40 \\
\hline 4 & Nanang & $\begin{array}{l}\text { Dk. Bacem RT 03/ } \\
\text { RW 05 }\end{array}$ & Male & Craftsmen & 47 \\
\hline 5 & Rubiem & $\begin{array}{l}\text { Dk. Bacem RT 03/ } \\
\text { RW 05 }\end{array}$ & Female & Craftsmen & 45 \\
\hline 6 & Pur & $\begin{array}{l}\text { Dk. Bacem RT 02/ } \\
\text { RW 05 }\end{array}$ & Male & Craftsmen & 47 \\
\hline 7 & Wardoyo & $\begin{array}{l}\text { Dk. Bacem RT 02/ } \\
\text { RW 05 }\end{array}$ & Male & Craftsmen & 35 \\
\hline 8 & Yanto & $\begin{array}{l}\text { Dk. Bacem RT 01/ } \\
\text { RW } 05\end{array}$ & Male & Craftsmen & 48 \\
\hline 9 & Suyono & $\begin{array}{l}\text { Dk. Bacem RT 05/ } \\
\text { RW } 05\end{array}$ & Male & Craftsmen & 50 \\
\hline 10 & yusuf & $\begin{array}{l}\text { Dk. Bacem RT 05/ } \\
\text { RW } 05\end{array}$ & Male & Craftsmen & 47 \\
\hline 11 & Sutopo & $\begin{array}{l}\text { Dk. Bacem RT 05/ } \\
\text { RW } 05\end{array}$ & Male & Craftsmen & 38 \\
\hline 12 & Susilo & $\begin{array}{l}\text { Dk. Bacem RT 04/ } \\
\text { RW } 05\end{array}$ & Male & Craftsmen & 48 \\
\hline 13 & Sarni & $\begin{array}{l}\text { Dk. Bacem RT 05/ } \\
\text { RW } 05\end{array}$ & Female & Craftsmen & 36 \\
\hline 14 & Indri & $\begin{array}{l}\text { Dk. Bacem RT 05/ } \\
\text { RW } 05\end{array}$ & Female & Craftsmen & 47 \\
\hline 15 & Wari & $\begin{array}{l}\text { Dk. Bacem RT 04/ } \\
\text { RW } 05\end{array}$ & Female & Craftsmen & 49 \\
\hline 16 & Wisnu & $\begin{array}{l}\text { Dk. Bacem RT 05/ } \\
\text { RW } 05\end{array}$ & Male & Craftsmen & 46 \\
\hline 17 & Sigit & $\begin{array}{l}\text { Dk. Bacem RT 04/ } \\
\text { RW } 05\end{array}$ & Male & Craftsmen & 47 \\
\hline 18 & Rusmini & $\begin{array}{l}\text { Dk. Bacem RT 02/ } \\
\text { RW } 05\end{array}$ & Female & Craftsmen & 39 \\
\hline 19 & Dono & $\begin{array}{l}\text { Dk. Bacem RT 02/ } \\
\text { RW 05 }\end{array}$ & Male & Craftsmen & 50 \\
\hline 20 & Kelsa & $\begin{array}{l}\text { Dk. Bacem RT 02/ } \\
\text { RW } 05\end{array}$ & Female & Craftsmen & 51 \\
\hline \multicolumn{5}{|c|}{ Total } & 905 \\
\hline
\end{tabular}

Source : Research Data Analysis 2018 
From previous table, it is known that the total grade of the interview results is 905 which mostly comes from interviewee named Mr. Wito with address at Dukuh Bacem RT 04 / RW 05. Even though he only graduated from high school but Mr. Wito already has a lot of sales to market the kite product. In addition, Mr. Wito is one of the biggest kite craftsmen compared to the others. The demand of his product is not only coming from the city of Solo, but also from other provinces such as East Java and Bali.

On the other hand, the lowest grade from the questionnaire was $\mathrm{Mr}$. Wardoyo who lives at Dukuh Bacem RT 02 / RW 05. He obtained the less grade and becomes the smallest craftman in the study area for several reasons : he has little capital, he has no sales, and the location of his business is less extensive. Therefore, orders of Mr. Wardoyo's product depends on other big Craftsmen like Mr. Wito, for example Mr. Wito can take Mr. Wardoyo's product in case his product is lacked in stock.

The average value can be obtained by means of the total value divided by 20 since the total number of respondents is 20 . The calculation follows the formula below:

1. Range:

[highest value - lowest value] $=51-35=16$

2. Average value:

Total Value $/ 20$ (total industry) $=45.25$

3. Classes:

If the range value $=16$, the possibility of classes is around 5 .

For practice, we use the rules of Sturges.

$$
\begin{aligned}
\text { Classes } & =1+3.3 \times \log (\mathrm{n}) \\
& =1+3.3 \times \log (20) \\
& =5.29 \approx 5
\end{aligned}
$$

4. Class Length:

Class Length $=[$ range $] /[$ classes $]$ 


$$
\begin{aligned}
& =16 / 5 \\
& =3.2 \approx 3
\end{aligned}
$$

From previous procedure, we obtain following information:

The number of classes $\quad: 5$

Class length $\quad: 3$

Lower class limit $\quad: 35$

Table 5. Measurement standard

\begin{tabular}{|l|l|}
\hline Total Measurement & Criteria \\
\hline $51-54$ & Very Good \\
\hline $47-50$ & Good \\
\hline $43-46$ & Sufficient \\
\hline $39-42$ & Deficient \\
\hline $35-38$ & Very Deficient \\
\hline
\end{tabular}

Table 6. Sampling Population

\begin{tabular}{|l|l|}
\hline Total Measurement & Sampling Population \\
\hline $51-54$ & 2 \\
\hline $47-50$ & 10 \\
\hline $43-46$ & 3 \\
\hline $39-42$ & 2 \\
\hline $35-38$ & 3 \\
\hline
\end{tabular}

Based on average value and measurement standard from the calculation above, then it results 45.25 as the average value. The number of kite craftsmen who have very good, good, sufficient, deficient, and very deficient range is $2,10,3,2$, and 3 respectively. 


\section{The Production Factor And Production Output That Support The} Existence Of A Kite Home Industry

The production factor of kite home industry includes various aspects, such as Business Capital, Raw Materials, Labor, Marketing, Industrial Locations. Based on interviews with all craftsmen, various types of information can be found regarding the factors of kite production in Grogol Village, Grogol District as follow :

\section{a. Business capital}

By interviewing kite craftsmen, almost all craftsmen have personal business capital without loan from banks or financial institutions. It because they gradually collected their money and eventually their business able to grow like current condition. In addition, it is unnecessary for them to have bank loan since making kites does not require much business capital, even many new Craftsments are getting involved in the process of kite-making producing.

\section{b. Raw material}

With the existence of Craftsmen association, the raw materials to support kite-making process will never be lacking. Good cooperation between craftsmen makes them easily find raw materials.

Bamboo as raw material to make kite frame is obtained by craftsmen from Wonogiri Regency. Craftsmen only need to contact bamboo producer by phone so it can be sent from Wonogiri by truck. So far, there is no problem regarding the lack of raw materials, so the kite-producing process can run smoothly.

Paper or plastic materials to make the kite body have also been supplied by middlemen from Kwarasan Village. If the stock of paper and plastic runs out, the craftsmen only need to go to Kwarasan Village to get them with affordable price. The raw material for both nylon and gelatin threads also 
has its own suppliers from Kwarasan Village. Thereafter, craftsmen have to divide them in various lengths according to price. Likewise, it is also applied to threads string since its raw material has been supplied from supplier. Craftsmens only need to provide yarn rollers for coating process in which the rollers can be derived from milk can and used textile rolls. In addition, craftsmen also labeled the thread's name so they could distinguish between expensive and inexpensive types of mat strings, whereas the thread rollers have been supplied by scrap collectors.

\section{c. Labor}

Labor is a vital factor that supports the progress of an industry. The kites production in Grogol Village only takes the workforce from the industrial area surrounding. Most of the kite industry is a family business, so the workforce is only from family members.

\section{d. Marketing}

Marketing is a determining factor in industry development. Good marketing will also result in the industry going forward. The marketing of kite industry in Grogol Village is overly smooth since it has no competitor from other villages. In addition, the customer of this industry is not only coming from the local area but also from other provinces such as East Java, Bali, and Lombok. Even, the execessive demand from buyers sometimes can make the craftsmen failing to fulfill it.

\section{e. Industrial Location}

The strategic location is the influential factor for an industry progress. This kite industry is located near the city center of Grogol Subdistrict that makes buyers easy to find out. Besides, the accessibility to this location is reachable where the customers can take either public transportation with square kidul direction or private car that only takes 5-minute trip from Solo Baru to get there. 


\section{CONCLUSION \& RECOMMENDATION}

\section{Conclusion}

From this study, it can be concluded that :

1. The kite home industry in Grogol has 20 craftsmen that is spread over the village

2. Based on the interview result, the socio-economic condition of kite craftsmen has been nearly good with score 45,25 that includes health, child education, and daily need fulfilment

3. The production factor of kite industry in Grogol has no obstacles in all aspects, including raw material, labour, industrial location, business capital, and marketing.

\section{Recommendation}

Some recommendations from this study are:

1. To improve and to enlarge the marketing area of this industry by adding more sales in other disctricts

2. To increase the labour in producing kite to fulfill the demand from customers so they can be satisfied 


\section{REFERENCE}

Damsar dan Indrayani. 2009. Pengantar Sosiologi Ekonomi. Jakarta: PRENADAMEDIA GROUP

Ig. Dodiet Aditya Setyawan, SKM. 2013. Disribusi Frekuensi. Poltekkes Kemenkes Surakarta. Pertemuan IV. http ://www.slideshare.net

Kamus Besar Bahasa Indonesia halaman 890 tahun 2011

Khoerudin, 2017. Koordinasi Eksternal Dinas Lalu Lintas dan Angkutan Jalan tentang Implementasi Sistem Satu Arah Kota Bogor. Jurnal Governansi.

Kiefer, and Lillesand. 1990. Penginderaan Jauh dan Interpretasi Citra. Jogjakarta: UGM Press.

Lestari,Sri. Tahun 2013. 45 Permainan tradisional anak Indonesia. Yogyakarta:langen sari publishing.

Marfai, Aris. 2015. Pemodelan Geografi. Yogyakarta : Ombak

Modul 3. analisis spasial. Bandung : Kemenristek, 2013.

Moleong, Lexy. J. 2007. Metode Penelitian Kualitatif. Bandung: Rosda Karya

Slamet, Wiyono. 2012. Management Potensi Diri. Jakarta: Grasindo.

Republik Indonesia tanggal 29 juni 1984. Undang - undang Nomor 5 Tahun 84 tentang perindustrian oleh Presiden. Lembaran Negara RI Tahun 1984, dibuat di Jakarta.

Republik Indonesia tanggal 26 Desember 1995. Undang - undang Nomor 9 Tahun 95 tentang Usaha Kecil oleh Presiden. Lembaran Negara RI Tahun 1995, dibuat di Jakarta.

Republik Indonesia 2014. Undang - undang Nomor 3 Tahun 2014 tentang perindustrian oleh Presiden. Lembaran Negara RI Tahun 2014, dibuat di Jakarta

Soekanto, Soerjono dan Budi Sulistyowati. 2015. Sosiologi Suatu Pengantar. Jakarta: RajaGrafindo Persada

Sugiyono, 2008. Metode Penelitian Kuantitatif, Kualitatif dan R\&D. Bandung : Penerbit Alfabet

Sutanto, 1994. Penginderaan Jauh dan Interpretasi Citra Jilid 1, cetakan III. Jogjakarta: UGM Press.

Sutanto, 1994. Penginderaan Jauh dan Interpretasi Citra Jilid 2, cetakan III. Jogjakarta :UGM Press

Tika, Moh. Pabundu.2005. Metode Penelitian Geografi. Jakarta: Gramedia Pustaka Utama 